\title{
Traveling Irishness in the Long Nineteenth Century
}

\section{Raphaël Ingelbien}

To cite this article: Raphaël Ingelbien (2019) Traveling Irishness in the Long Nineteenth Century, English Studies, 100:2, 244-246, DOI: 10.1080/0013838X.2019.1566851

To link to this article: https://doi.org/10.1080/0013838X.2019.1566851

曲 Published online: 18 Feb 2019.

Submit your article to this journal

Џ Article views: 6

View Crossmark data $\nearrow$ 
on Mary Magdalene and the hortulanus sequence. Here he offers complex and compelling readings of Herbert's "The Bag", "The Bunch of Grapes", and "Love Unknown" as well as Vaughan's "The Night" to show how the Johannine rhetorical devices of misunderstanding and irony fundamentally shape those poems.

Given the scope of his project, it would be easy for Cefalu's argument to oversimplify some of the theological and literary nuances he explores. That is, however, not the case. The chapters are consistently thorough, meticulously researched, and thoroughly engaging. The Johannine Renaissance will be of special interest to scholars of Henry Vaughn and George Herbert. Cefalu's treatment of their work adds fresh perspectives on their devotional poetry, theology, and rhetoric. Donne and Milton scholars will find much in Cefalu's exploration of the Johannine Paraclete. The book does, unfortunately, have a dearth of focus on gendered uses of Johannine discourse, which Cefalu acknowledges in his Afterward where he alludes to Anne Hutchinson and Rachel Speght, two authors whose work is undoubtedly influenced by Johannine discourse. I would have liked to see his final chapter turn to these authors rather than returning to Herbert and Vaughan who were well-treated in earlier sections. To be clear, the final chapter's treatment of Herbert and Vaughan is still excellent. I would welcome a future work in which Cefalu applies his rigour and careful analysis to Hutchinson and Speght.

In sum, Paul Cefalu's Johannine Renaissance in Early Modern Literature and Theology is a book well-deserving of study and reflection. It rewards both. Its cross-disciplinary appeal warrants it a place in the libraries of theologians and literary scholars alike.

J. Seth Lee Department of English, University of Alabama in Huntsville, Huntsville, AL, USA Q j.sethlee@uah.edu

Traveling Irishness in the Long Nineteenth Century, edited by Marguérite Corporaal and Christina Morin, Cham, Palgrave Macmillan, 2017, 258 pp., £67.99 (hardback), ISBN: 978-3319525266

Much has already been written on Irish exiles, migrants and diasporas: if Traveling Irishness builds upon significant work in those areas, it also expands its scope by considering not just how Irish people moved out of Ireland, but also how Irish artefacts, writings and ideas started circulating worldwide in the long nineteenth century. The volume's choice of period reflects a well thought-through thematic focus on the material conditions that boosted international movements and exchanges to a point where, on the eve of the First World War, the globe was interconnected as never before. It was through technological innovation that revolutionised transport and print, measures facilitating trade, and new translation practices that Ireland "travelled" - sending out not just migrants, but also tourists or travellers whose movements elude categorisation, and all manner of goods (though only cultural goods are considered here).

The editors' chronological choices are further intended to place the most epochal mass movement out of Ireland in a broader context. The aim is not to divert attention from the exodus caused by the Famine of the late 1840s, whose shadows still loom over several essays collected here, but to attend to modern patterns of migration that either predated the 
Famine or persisted long after the disaster. Moreover, both the nature and the destinations of "travel" are also expanded: as the rationales for Irish journeys and exports multiply, so do the locations that are considered. While previous studies dealing with specific forms of Irish travel generally zoom in on destinations circumscribed by geography, politics or language, this collection enables readers to range freely across the globe, thus adequately conveying the sense of global interconnectedness that was created over the period it examines.

A first section opens with essays devoted to Irish travels on the European mainland. The focus is mostly on accounts by individual travellers. After a sketch of the factors that linked Ireland to Italy, Anne O'Connor provides an engaging reading of Julia Kavanagh's 1858 Italian travelogue in the light of the author's intermittent but ultimately keen awareness of her Irish background. Peter Gray then discusses the Italian writings of Mabel Sharman Crawford, a neglected Ulster author whose radical politics informed her analyses of social issues in the peninsula: the comparative gaze she developed both refined her insights into local contexts and helped her transcend them in the feminism she pursued in later life. In his essay on Maria Frances Dickson, Joachim Fischer examines another forgotten Irish traveller's accounts of Germany and of Ireland, drawing contrasts with similar travelogues by English women writers and emphasising the importance of the place where Irish travellers published versions of their texts.

The volume then moves on to a more heterogeneous discussion of "genre, movements and forms". Anne Cormican discusses the resolutely and innovatively cosmopolitan aspirations of certain Irish art collectors and artists at the turn of the century. Marguérite Corporaal analyzes the place that translations of Irish local-colour fiction occupied in European literary markets where the genre became increasingly popular. Peter O'Neill sketches the wandering existence of James Connolly as a socialist thinker in search of a politically congenial environment - a quest which led him to travel up and down North America before he went back to Ireland to die as a nationalist martyr.

A shorter third section on "representations of traveling" combines Matthew Reznicek's close reading of the Parisian chapters of Maria Edgeworth's 1817 novel Ormond with Jim Shanahan's wide-ranging survey of the travelling types who people the fiction of Charles Lever, himself a much experienced traveller. Reznicek shows how Ormond's Parisian episodes, far from being an interlude, are fundamental to the linkage that Edgeworth effects between Ireland and the continent through Enlightenment ideas of community embodied in new modes of dramatic experience. Shanahan divides Lever's travelling protagonists into soldiers of fortune, tourists and "Irishmen in reverse" - if the first two types often confirm Lever's talent for comic caricature, the third constitutes a small but fascinatingly complex cast of exilic heroes with an Irish outsider's perspective on their "home" country.

The volume closes with three essays devoted to the international circulation of Irish literary idioms. Christina Morin examines the prominent role that needy Irish writers played in the massive output of popular novels published by William Lane's London-based Minerva Press, and the dissemination that those novels achieved through sales and reprints in a global Anglophone market - a movement that appears uncannily and proleptically mimicked by the geographical shifts that feature in many of the novels' plots. Jason King charts the adaptations that the genre of the national tale, pioneered by Irish Romantic-era novelists like Owenson and Edgeworth, underwent when writers of different persuasions and nationalities adapted its tropes in fiction dealing with the presence of Irish nationalists in North America. Meidhbhín Ní Úrdail's essay on Thomas O’Connor shows how Irishness did not depend on the English language to travel: a Cork scribe who had settled in London in the 1820s, O'Connor promoted Irish-language culture in the British metropolis and kept involved in relevant developments in Ireland for much of the early to mid-Victorian period, i.e. decades before the Gaelic League's "revival" of interest in the language both at home and in the diaspora. 
The general sense that emerges from this volume is not just that nineteenth-century Ireland, despite its perceived peripherality and backwardness, conformed to a general trend towards globalisation. Various essays end up claiming Ireland as paradoxically central to the age's emerging global networks: by producing the travel narratives or popular novels that the age demanded, or by supplying the exiles and émigrés who easily fitted in transnational ideologies, Ireland often seemed to play a pivotal role in the creation of a global culture. This may sound familiar in our own more recent age where Celtic Tiger Ireland became a poster child for globalisation, and where River Dance, the Irish pub, Enya and U2 conquered the world. Yet the picture painted by Traveling Irishness is a different one. Indeed, several essays show how travelling Irish subjects and artefacts had to negotiate compromises that watered down their Irish dimension - for instance, the "regional" Irish fiction that lent itself most to translation was the kind of narrative that did now dwell too much on the details of Irish locale, but rather emphasised a sense of dislocation brought on by modernity that readily echoed with audiences in other countries. The travelling Irishness considered here thus points forward to, but also differs from the contemporary success of "brand Ireland", which reflected a newly gained sense of national self-confidence. Cormican's essay on the visual culture of fin-de-siècle Ireland describes conflicts between internationalist ideals and the inward-looking art of the "racy of the soil" variety advocated by Revivalists. In the end, however, those same insular Revivalists were arguably responsible for the culture associated with the "brand Ireland" of more recent global fame, while the internationalists sometimes became mere footnotes in narratives about Irish identity, both within Ireland and abroad. It is not the least merit of Traveling Irishness that is has recovered many such footnotes from oblivion, and that it can prompt us to think further about different waves of globalisation.

Raphaël Ingelbien

KU Leuven

ه raphael.ingelbien@kuleuven.be

(C) 2019 Raphaël Ingelbien https://doi.org/10.1080/0013838X.2019.1566851

Check for updates

Robert Lowell: Setting the River on Fire, a Study of Genius, Mania, and Character, by Kay Redfield Jamison, New York, Alfred A. Knopf, 2017. xii + 527 pp., \$29.95 (hardback), ISBN 978-0307700278

Kay Redfield Jamison's Robert Lowell: Setting the River on Fire is a tour de force. It was something of an event when it came out, eagerly anticipated by Lowell scholars as well as by admirers of Jamison's earlier work. The author of well-known textbooks on manic-depressive illness and of the iconic memoir An Unquiet Mind, Jamison's take on Lowell would always be out of the ordinary. Yet Setting the River on Fire has become a truly extraordinary book, and not just because Jamison was the first scholar to access Lowell's medical records. The most famous American poet after World War II, Lowell notoriously suffered from a bipolar condition, but the way that this disease controlled his life and art, we can now finally see was never properly understood. Setting the River on Fire is "a study of genius, mania, and character," as the subtitle reads, but it doubles up as a revisionary biography of Lowell, with flourishes of memoir, and interspersed with terse cultural reflections on mania and melancholia, ranging from Ancient Greek writers to modern psychologists. Jamison also takes a profound interest in Lowell's ancestral history, as becomes luminously clear in the biography's evocative opening 